\title{
SOME PLATONIST READINGS OF ARISTOTLE ${ }^{1}$
}

The first point I should make is that 'Platonist readings' in the context of this paper means the reading of Aristotle by Neoplatonist interpreters who were armed with powerful Platonic prejudices. If I have avoided starting with the description 'Neoplatonist' that is because the philosophers involved would not so have described themselves. Notoriously they thought that they were Platonists, and, moreover, Platonists like Plato himself. This might be thought to be pointless reiteration of what is 'allgemein bekannt' - if not well-known - but it does have some bearing on the present subject, for it meant that the commentators were trying to find in Aristotle the thought of Plato as they understood it. Had they thought of themselves as 'Neoplatonists', with a full historical consciousness of the implications of that term, and, in particular, an awareness of how some parts of Plato's thought had, in the course of the Platonic tradition, been thoroughly Aristotelianised, they could not have approached Aristotle in the way that they did.

At this stage it might be as well to set out a few facts and also some assumptions which I shall try to prove, or illustrate, by looking at a few samples of the late Greek interpretation of Aristotle.

First, the Platonist commentators assumed that Aristotle was normally expounding the same doctrines as Plato: ${ }^{2}$ I use the words 'expounding ... doctrines' advisedly. When he appeared to be taking a different line, that was usually a deceptive appearance, and the difference would, on closer inspection, be revealed as illusory. They were usually, it was alleged, produced by a misunderstanding of Platonic texts, or by paying attention to the letter rather than the spirit of Aristotle's remarks: so for instance Simplicius in his de Caelo commentary (640.2732). ${ }^{3}$ The view that merely verbal differences were responsible for the apparent exceptions was not of course new. It can be found as early as Antiochus in the first century B.C.,${ }^{4}$ and so was very firmly embedded in the Platonist tradition by the fifth and sixth centuries A.D. On a few points, however, disagreements were accepted as genuine and seen not be amenable to the processes of resolution. ${ }^{5}$

Now, if one combines the presuppositions that one is oneself a mere exponent of Plato, and that Plato and Aristotle held the same views on almost all matters of importance, it follows that on any given point one's own views and Aristotle's should normally be the same. And if, to look at it from our point of view, one were a Neoplatonist, one would explain Aristotle as if he were a Neoplatonist too. This may seem to be a rather wild conclusion, and one that should not be accepted without further argument and documentation. In so far as these are needed I hope I 
have said enough elsewhere to show that it is not an unreasonable conclusion, ${ }^{\mathrm{b}}$ and so should like to take it as a working hypothesis now.

One further point should, however, be made. It might be objected, firstly that the Aristotelian commentators could not have been so imbued with Platonism as not to see that the exposition of Aristotle required a certain detachment from their own views, and secondly that the commentators were not as thoroughly Neoplatonist in their own thought as those of their predecessors and contemporaries who wrote either independent works or commentaries on Plato - men like Proclus and Damascius. The answer to the first objection is that they were so imbued and did not see the requirement - Themistius is a counter-example, and much earlier, who does not alter the general picture ${ }^{7}$ - and to the second that they quite clearly were. Nor incidentally, was there any major difference between the philosophical frameworks of the views held by members of the so-called schools of Alexandria and Athens. Though it has long been thought that there was, ${ }^{8}$ it is prima facie unlikely because of the constant interchange of students and teachers between the two centres, ${ }^{9}$ and is in any case being shown to be untenable by work done in the last few years: Mme. Hadot's work on Hierocles and Simplicius comes most readily to mind. ${ }^{10}$ The reason why those who taught and wrote at Alexandria concentrated on Aristotle had more to do with politics and religion than philosophy, as Professor Alan Cameron pointed out in a paper presented to this society in 1969.11

As a corollary of the theory that Aristotle's thought was the same as Plato's, and that a Neoplatonist was merely saying more clearly what Plato had sometimes put obscurely, 12 the commentators also assumed that any Platonist who discussed the same problems as Aristotle was thereby expounding Aristotle. This also I have argued elsewhere, ${ }^{13}$ and so do not intend to spend time on it now. It meant, for instance, that anything Plotinus, or Plutarch, or Proclus said about the intellect could be taken as discussion of chapters 4 and 5 of Book 3 of the de Anima, and was so taken, as the doxography in the pseudo-Philoponus commentary on de Anima 3.5 makes all too clear. ${ }^{14}$

Let us now look at some texts which show, or may be argued to show, the results of writing Aristotelian commentary on the basis of these assumptions. In the field of psychology, from which they are taken, one might foresee particular difficulties arising from the need to reconcile the dualist Platonic view of the soul with the hylomorphic Aristotelian one. Thus the most severe difficulties might appear at the most obvious points of conflict. These would include the definition of soul, its relation to the body, and in a different way, the status of its highest part, where the theories of Plato and Aristotle might most easily be held to coincide, but where matters were complicated by internal Neoplatonic controversies about the intellect. ${ }^{15}$ The texts I want to examine here are mainly about questions where matters are less clear cut or obviously controversial, and where in consequence the more obvious signs of distortion might not be expected.

Once they had redefined Aristotle's soul in a Platonic way - I put it like this 
because they did in fact transpose Aristotle's definition into a Platonist mode ${ }^{16}$ - the Neoplatonists did to a large extent use Aristotle's way of explaining how the soul worked. Their divergences from Aristotle can often be explained in terms of special Platonist problems such as the need to show that the soul is not, or rather is not 'really', affected by the body, or peculiarly Neoplatonic problems like the soul's relation to the higher hypostases and, where applicable, their contents. ${ }^{17}$

One symptom of Neoplatonizing interpretation is a persistent tendency to solve problems, or rather, to attempt to solve them, by a multiplication of entities. This can be seen at all levels in the system. Wherever the relation between two entities $A$ and $B$ is unclear, the later Neoplatonists' favoured solution was to interpose a third, characterised by being either not $\mathrm{A}$ and not B, or both $\mathrm{A}$ and B. ${ }^{18}$ Signs of this tendency can be seen from Plotinus onwards, but it probably did not become standard practice until lamblichus. ${ }^{19}$ By the time of the late commentators it had already been an established method for two or three hundred years. It was one way in which they managed to attach the Platonic soul to the body in conformity with the Aristotelian definition of soul. The same excessively realist tendency can be seen at work when problems about the soul's activities are 'solved' by the creation of further levels of soul to correspond to activities or functions whose operation, or status, was problematic.

A case in point is their treatment of how we know that we are perceiving, and the adjacent questions about how we perceive the 'common sensibles' and discriminate between the objects of the several senses which Aristotle discussed in de Anima 3.1 and 2 , and notoriously left unclear. Since it is not my present purpose to discuss problems in Aristotle as such, I hope I may be allowed to assume that whatever he did propose on any of the occasions on which he discussed these matters he did not establish an extra sense over and above the five, nor did he admit an extra faculty, sensitive or other, that somehow processed the products of the ordinary senses or abstracted information from the 'i $\delta \iota \alpha$ ai $\sigma \vartheta \eta \tau \dot{\alpha}$. While it might be argued that he came close to doing so in the Parva Naturalia, ${ }^{20}$ in the de Anima it is clear that the perception of common sensibles, though it does of course differ by the possibility of error, is not all that different from the perception of special sensibles. Nor is discrimination between the objects of special senses, which Aristotle sees as the work of the sensible faculty working as a whole. All these questions were treated under the heading Koเvì ai $\sigma 9 \eta \sigma ı \zeta$ by the commentators, though, as is well known, the term appears only once in de Anima (425a27) and only infrequently elsewhere. Yet if one reads the interpretation of de Anima 3.2. in Simplicius one might well think that Aristotle's views were not at all as I have indicated. I shall, if only for convenience, continue to call the author of this commentary Simplicius even though his authorship of it has recently been questioned. ${ }^{21}$

In the first place Simplicius' comments manifest the usual Platonist concern, which cannot be Aristotle's, to show that the soul retains its ả $\pi \alpha \dot{q} \varepsilon\llcorner\alpha$ even in those activities where it is necessarily involved with the body. Thus Simplicius takes the 


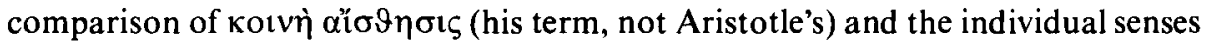
to a point at which two lines coincide (427a9-13) not primarily as an illustration of how the senses may come together, but of how the operation of perception is free

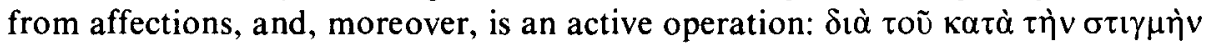

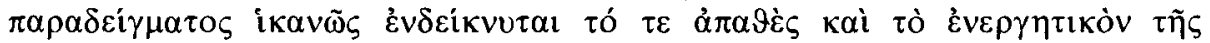

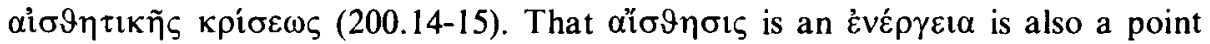
which Neoplatonists had emphasised since Plotinus. They were concerned, inter alia, to differentiate their view as far as possible from views that involved, or were

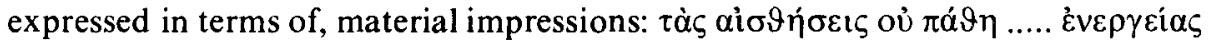

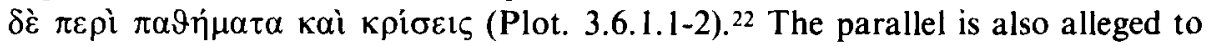
show that perception is $\dot{\alpha} \mu \varepsilon \varepsilon^{\prime} \sigma \tau$, , and that, as Simplicius goes on to remark, is related to the fact that the activities of $\dot{\alpha} \mu \dot{\varepsilon} \rho ı \sigma \tau \alpha$ are themselves $\alpha \mu \varepsilon \dot{\varepsilon} \rho ı \tau \tau$. Here we have the special terminology of Neoplatonist discussion of the soul, whose nature was characteristically defined through a discussion of the divisibility or lack of it of various levels of existence, offered by way of exposition of Timaeus 35A:23 the topic was perhaps suggested here by Aristotle's use of $\alpha \delta \delta^{\alpha} i \rho \varepsilon \tau o v$. Soul is indivisible in

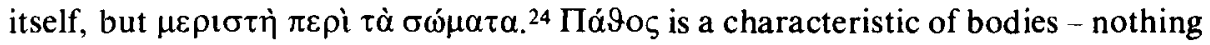
un-Aristotelian about that - which are oủ $\sigma i \alpha \mu \varepsilon \rho \iota \sigma \tau \eta$. Hence Simplicius' comment

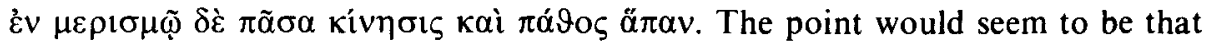

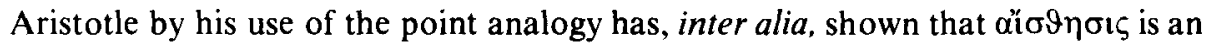
activity free from any taint of divisibility, and so an activity appropriate to soul unaffected by body. What Simplicius is doing is finding in the text of the de Anima further evidence for his own theses about the nature of the soul. That is why his commentary contains a series of observations which are of the most dubious relevance. His points are summed up a few lines below where we read $\sigma \tau \imath \gamma \mu \tilde{\eta}$ toívov

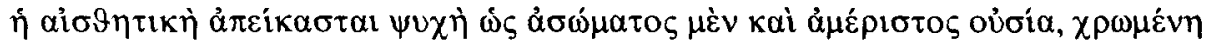

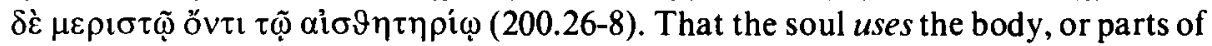
it, is, of course, another piece of Platonizing. An Aristotelian soul, being the form of the body, cannot use it. That notion is, of course, much older than Simplicius and could be traced back to the Alcibiades I (129D-130C), or even to a passing remark in the de Anima itself at 407b 27. Simplicius introduces it into his explanation of Aristotle's definition of the soul, an explanation which it might be useful to consider briefly at this point. ${ }^{25}$

Prima facie Aristotle's definition should be rejected by Platonists. But that would be to give in to the outward meaning of the words as opposed to finding their real sense. Accordingly Simplicius splits the soul at the level where it relates to body into two levels, one of which forms the body, and another which uses the body as its öpravov. This second level, with its function thus defined, might be said to pay attention to anything but the surface meaning of Aristotle's text, for what Simplicius has done is to take the word ópravtkóv, which Aristotle gives us as a description of the type of body soul informs, and to use it instead as a description of the status of that body (90.29-91.4). He has, further, used it as an expression of the 
subordination, as a separate entity, of what Aristotle regarded as belonging to a

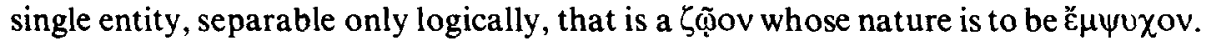
Simplicius has not merely chosen to ignore this fact, but in an earlier passage (52.26-9), actually reprimands Alexander for failing to see that the soul should be split into what uses the obyavov and what gives it its form.

That short but highly perverse exposition of Aristotle's definition not only helps to put in their context the comments we have been considering but also explains the

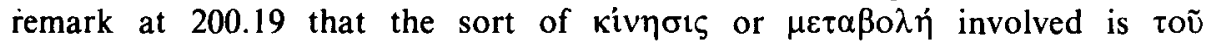
$\varepsilon i \delta o \pi \varepsilon \pi o ı \eta \mu \varepsilon ́ v o v$. That, we can now see, means body as organised by that level of

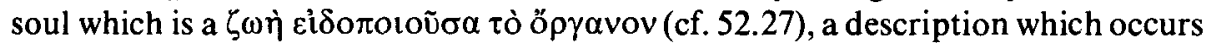
in the course of Simplicius' commentary on Aristotle's preliminary discussion of earlier theories of the soul.

In his criticism of the Platonists Aristotle explains that they disregard the usual understanding of the soul as something that is in body. By isolating the soul, and saying nothing about body, they allow it to turn up in any body and yet, says

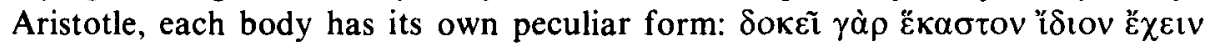

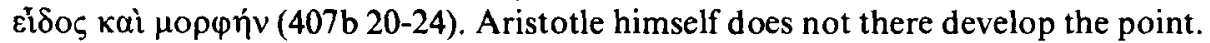
Simplicius, however, takes it as a cue to embark on a discussion of how soul relates to body, filling, we may notice, the gap Aristotle had found in Plato's account. If one had put it to him, Simplicius might well have accepted that this was one of the ways in which one might, as Plotinus had put it, say more fully what Plato had said in a concentrated, inexplicit way: $\mu \grave{\eta} \alpha v \alpha \pi \varepsilon \pi \tau \alpha \mu \varepsilon \dot{v} \omega \varsigma$ (Plot. 5.1.8.11-12). Be that as it may, he offers some observations on the body and how soul relates to it which are, as we shall see, more closely connected with Neoplatonic thinking on these subjects than with either Aristotle's or Plato's. His first point is that the body which is to be

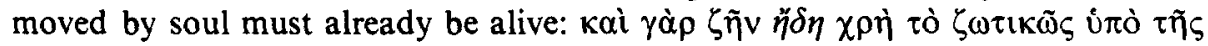

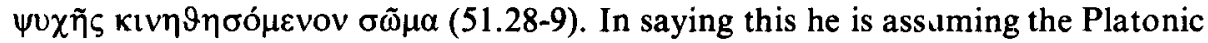

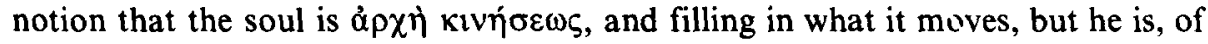
course, filling in too much, since Plato's body would not live without its soul, nor would it make sense to talk of a living body without soul in Arıstotle. But in Neoplatonic terms the comment is unremarkable because it accords with the standard account of soul's relation with body - there are variations - by which soul was added to a body which was already endowed with an element of soul in virtue of which it became body rather than mere matter. This view of a $\sigma \tilde{\omega} \mu \alpha$ as (matter + soul) + soul may be found in Plotinus' odd critique of the ' $v \tau \varepsilon \lambda \dot{\varepsilon} \chi \varepsilon 1 \alpha$ doctrine in 4.7.85.26 Plotinus does in some ways stand outside the Neoplatonic tradition and one of the ways he does so is by failing to see, or seek, what many of his successors

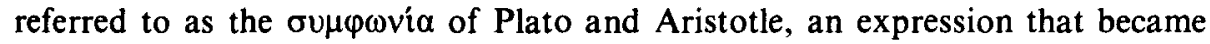
something like a slogan. ${ }^{27}$

To return to Simplicius. He continues his commentary by claiming that it was this sort of distinction which Aristotle required, one which distinguished the life of body from the soul which was in the position of user. The first is that which gives 
body its form - $\varepsilon \dot{i} \delta \circ \pi \circ o v \sigma \alpha \alpha$ again - as an ö $\rho \gamma \alpha v o v$, and a thing that is moved with

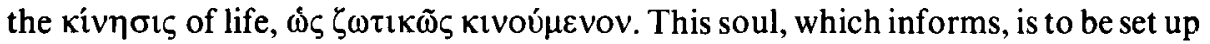
as like that which always uses it (51.29-33). It is, moreover, to be received by a body which is in every way fitted to do so, so that it might be suitable to participate in it. This seemingly innocuous statement is not only couched in Neoplatonic jargon, but

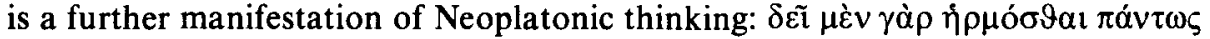

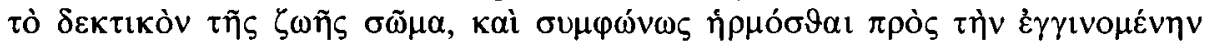

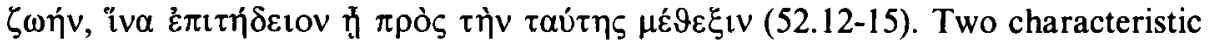
Neoplatonic doctrines appear in these words, the first that body must be in state of fitness to receive form, soul, or any other manifestation of higher being. As early as Plotinus we are told, somewhat paradoxically, that body will receive as much soul

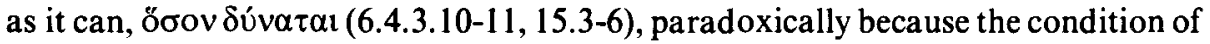
body is itself a product of soul; ${ }^{28}$ the later Neoplatonists regularly used $\dot{\varepsilon} \pi \imath \tau \eta \dot{\delta} \delta \varepsilon$ and $\dot{\varepsilon} \pi \imath \tau \eta \delta \varepsilon 10$ c $\eta \zeta$ to express this notion. ${ }^{29}$ The second is that all lower entities relate to those above by $\mu \varepsilon \hat{\varepsilon} \xi_{1} \iota_{\zeta}$ : this is no longer confined to the relation of particulars to forms, but is to be found as one way in which all levels of being are linked - or negatively related..$^{30}$ One of the implications of this metaphor is that the higher reality is more extensive than the lower, an implication which makes the idea particularly appropriate as part of the argument against the $\alpha \rho \mu o v i \alpha$ view of soul. But it is clearly not one that Aristotle himself could have used. One reason for the prevalence of the $\alpha \rho \mu$ ovi $\alpha$ view was, according to Simplicius, that people failed to

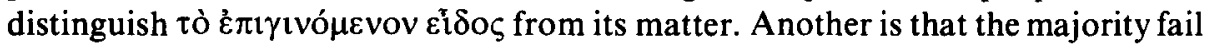
to make the distinction between the $\zeta \omega \eta$ which uses the ópravov and that which

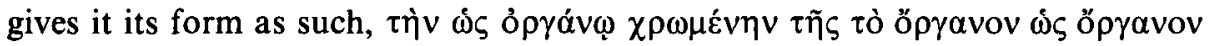

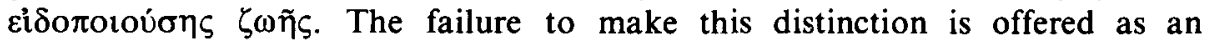
explanation of why Alexander of Aphrodisias mistakenly thought that soul does not use body as an instrument (52.27-9). ${ }^{31} \mathrm{~A}$ similar complaint about Alexander may be found when Simplicius is discussing Aristotle's example of eye and vision as

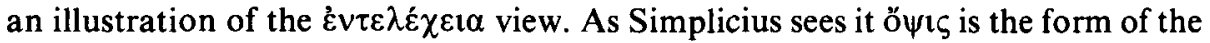

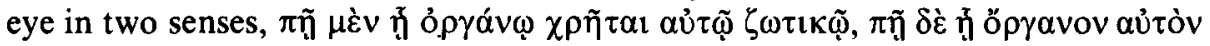

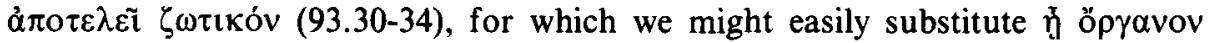

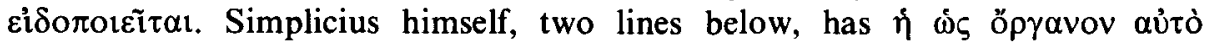
$\chi \alpha \rho \alpha \kappa \tau \eta \rho i \zeta o v \sigma \alpha$ ŏ $\psi 1 \zeta$ (93.36-7). According to Simplicius Aristotle in this parallel does not, as we might think, and Alexander did, intend the eye to be a mere body without vision. Simplicius takes Aristotle's point that the eye without vision is an eye only homonymously (412b 19-21), which might appear to support Alexander,

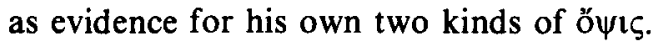

While all those commentators who were Neoplatonists were liable to read Neoplatonism into Aristotle, it must not be thought that their views on Aristotle, or their views as Neoplatonists, were necessarily identical. Stephanus, the pseudoPhiloponus, in his discussion of de Anima 3.2 also has recourse to explanations in terms of extra levels or layers of soul. While he is less puzzled about the common 
sensibles, he is unwilling to accept that we may perceive that we are perceiving by means of the ordinary senses. And as he accepts from Aristotle that there can only be five, he raises the function of perceiving that we perceive to the rational soul. $\mathrm{He}$ does not, however, simply attribute it to any of the usual faculties of that soul but

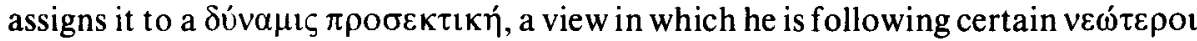
$\dot{\varepsilon} \xi \eta \gamma \eta \tau \alpha i$, whose identity remains unclear (465.31-466.29). Thus Stephanus' explanations are of the same kind as Simplicius', but their content is different.

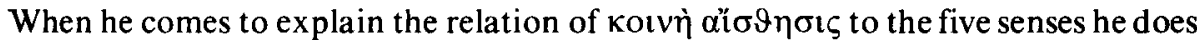
not omit to bring in the pneumatic body: that is, according to him, the $0 \pi \circ \varepsilon \varepsilon i \mu \varepsilon v 0 v$ whose $\pi \alpha \dot{q} \eta$ a common power perceives (481.18-22). That he is using pneuma in this rather than some other sense is indicated by the subsequent remark that Aristotle

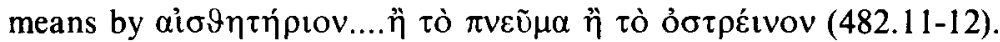

With these points in mind let us look at Philoponus' comments on the sections of de Anima 1 we have just considered. We shall find that he shares the approach we have seen, but that in his case too there are differences in the details. It might be worth adding that his Neoplatonizing is perhaps less comprehensive than that of Stephanus on Book 3 but it is certainly there. Any doubts on that score could be resolved by a reading of Philoponus' introduction, twenty pages of Neoplatonic philosophy which are hardly ever read. Any idea that Philoponus might be an unprejudiced commentator would not be likely to survive their perusal. They will also show us that differences between his commentary and that of Simplicius cannot be attributed to any alleged differences between Alexandrian and Athenian varieties of Neoplatonism. ${ }^{32}$ Nevertheless, within the constraints indicated above, Philoponus does seem to be prepared to follow Aristotle's thought more closely.

As a first indication of this we may notice that he treats matters arising from the

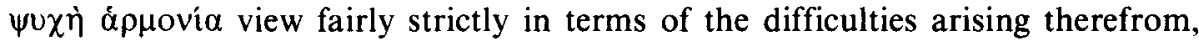
rather than by the immediate injection of Neoplatonist concepts with which it is incompatible, the technique we observed in Simplicius. In particular Philoponus follows Aristotle's set of arguments against the view as they are to be found in the de Anima and Eudemus ${ }^{33}$ (139.19-149.31). But when he deals with the more general point about a body being suitable for the soul we find that he is both introducing Neoplatonic notions, and adducing Platonic material which, he maintains, indicates that Plato did not neglect this point. He refers to the passage about the shape and position of the head in the Timaeus (44DE) and the other discussions there about the suitability of parts of the body for the other two parts of the tripartite soul. The introduction of these Platonic points might be seen as another sign of the procedure of attributing differences between Plato and Aristotle to misreading, or inadequate reading, of one or the other, in this case Plato. Such an explanation of Philoponus' approach is not invalidated by any opinion we may have that he is guilty of ignoratio elenchi in so far as the need for a round head to

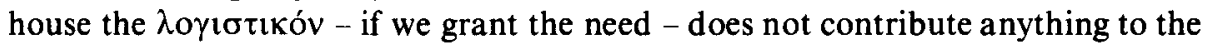
point that concerned Aristotle, namely why any particular soul should be in any 


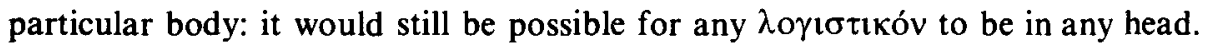
Prima facie however, it does meet the Neoplatonist requirement than an entity should be $\varepsilon \pi \tau \tau$ ́r $\varepsilon$ tov to receive what is above. On the following page Philoponus says in so many words that Plato was making Aristotle's point that not just any soul can go into any body before him: he finds it in the Phaedrus, where Plato says (249B) that no soul which has not seen tò öv could go into a human body (141.1017). This is explained in Neoplatonic terms as not applicable to the sensible world because that is in potentiality, and so in not-being, another conflation of Aristotle

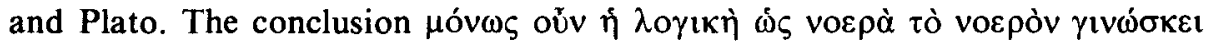
(141.20) uses an infrequent Aristotelian distinction first translated into Neoplatonic usage and then related to Neoplatonic spheres of being. $\Lambda$ oүıкทे $\psi v \chi \dot{\eta}$ is not a normal division in the de Anima, and to describe it as voepó suggests that we are to understand $\lambda$ oүik $\dot{\eta}$ in Philoponus' sense, that is all of the higher soul, including voṽ, but with its highest part still separate from what was above. That perhaps requires explanation: the point is that the term $\lambda$ o intended to exclude an undescended higher part of soul in which some Neoplatonists believed, ${ }^{34}$ and which Philoponus and Simplicius, as well as Stephanus, excluded from the de Anima, and in particular from the possible interpretations of the active intellect in 3.5, on the simple if inadequate grounds that

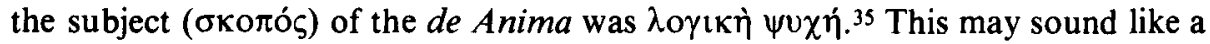
case of petitio: it is.

Further Neoplatonic elements may be found in Philoponus' treatment of Aristotle's preliminary discussion in 1.1, where he first raises the question about the

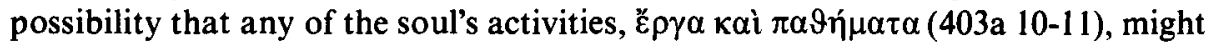
be peculiar to it, so that the soul would be separable. This text, like others where Aristotle tentatively notes it as a problem that there might be a separable part of the soul, caused difficulties for commentators who were certain that soul as a whole

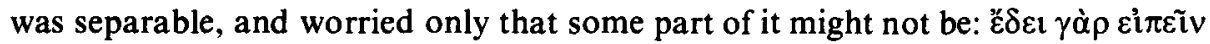

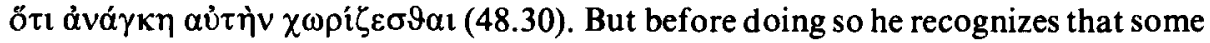
activities like locomotion are inseparable from the compound of body and soul. If the soul were entirely separate from the body, how would it be able to cause movement and reproduction? But both discursive and intuitive thought, which do

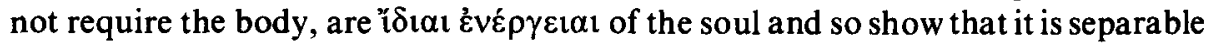
in its essence (48.16-22). This position, that the soul is essentially separable from the body but sometimes associated with it, is based on a split between its ovi $\sigma i \alpha$ and its

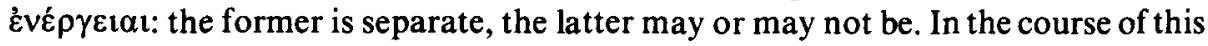
discussion Philoponus also gives his solution to the notorious problem about the soul being like a $\pi \lambda \omega \tau \eta \dot{\rho}$ which Aristotle throws out at 413a9. Translating Aristotle's $\pi \lambda \omega \tau \eta$ p into $\kappa \nu \beta \varepsilon \rho v \eta \tau \eta \dot{\zeta}$, an important move that appears to have been made at least as early as Alexander in what seems to be a deliberate attempt to fudge the problem, ${ }^{36}$ he claims that the $\kappa \cup \beta \varepsilon \rho v \eta \tau \eta \zeta \zeta$ acts both qua $\kappa \cup \beta \varepsilon \rho v \eta \tau \eta \zeta \zeta$ and qua man: his actions in the former capacity are inseparable from the ship whereas his 


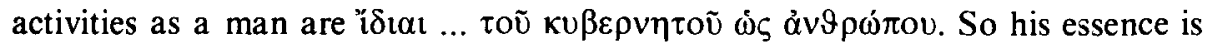
separable, whereas for it to be inseparable all his activities must be shared (48.2-10). Though the point does not occur here, these distinctions, and the reference to $\delta 1 \tau \tau \alpha i$

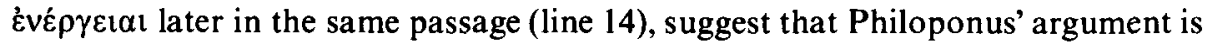
related to the commonplace Neoplatonic distinction between internal and external $\dot{\varepsilon} v \dot{\varepsilon} \rho \gamma \varepsilon ı \alpha 1 .{ }^{37}$ The internal $\dot{\varepsilon} v \dot{\varepsilon} \rho \gamma \varepsilon ı \alpha$ works on the same level as the entity of which it is one, the external on a lower level, and such a relation could be seen in the

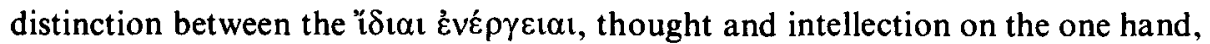
and those that go with the body on the other. In any case, Philoponus continues to

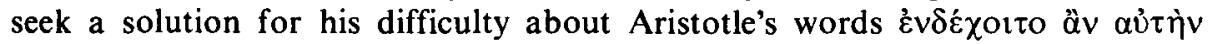
$\chi \omega{ }^{\prime} \zeta \zeta \sigma \vartheta \alpha \mathrm{\alpha}$. He suggests that Aristotle has in mind the soul's relation to body, or bodies as a whole: so long as soul is in body it is inseparable, and so he, that is, Aristotle, says it can be separated if it is to be reincarnated and not for ever remain

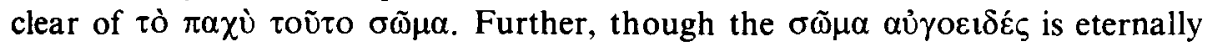
linked to the soul, Philoponus speculated that Aristotle may have been thinking of that when he used $\dot{\varepsilon} \delta \delta \varepsilon \dot{\varepsilon} \varepsilon \tau \alpha$, because the soul could be separated from it even if it is not necessary that it should be (48.22-49.8). This reasoning would, of course, have been incomprehensible to Aristotle since it rests on the Neoplatonic assumption that the soul was connected to body by a mediating pneumatic body or vehicle, or two of them. Philoponus subscribed to the latter version. ${ }^{38}$ The $\alpha \dot{\gamma} \gamma o \varepsilon ı \delta \grave{\varepsilon} \varsigma$ ö $\chi \eta \mu \alpha$ was one that the soul acquired on being destined for incarnation, the second, which was the basis of the common activities of body and soul, connected it with the body

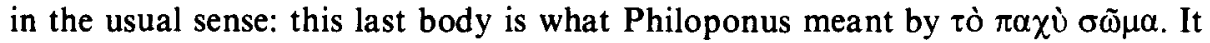
might be thought that Philoponus is just talking in his own terms and cannot possibly have attributed these penumatic bodies to Aristotle: he does not after all do so explicitly. Nevertheless it is highly likely that he simply assumed that Aristotle did believe in them, and we may recall that Proclus had made the attribution explicitly (in Tim. 3.238.19-21). To think that Aristotle held this view was not difficult, given the assumption that Aristotle and Plato held the same opinions, and

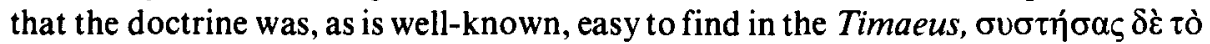

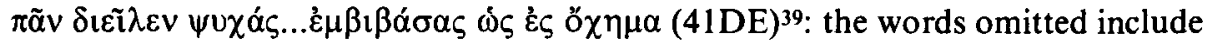

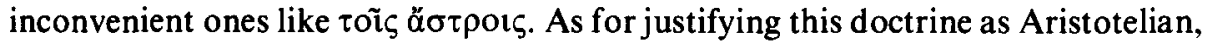
the commentators did not apparently feel obliged to adduce such references to pneuma, and particularly $\sigma u ́ \mu \varphi v \tau o v \pi v \varepsilon \tilde{\mu} \alpha$, as might have been pressed into service.

The subject of $\sigma u ́ \mu \varphi v \tau o v \pi v \varepsilon \tilde{\mu} \mu$ as an explanation of how soul imparts movement to body is one which in this college I can only approach with an extra access of $\alpha i \delta \omega \varsigma,{ }^{40}$ but there are to my knowledge no clear signs that the commentators saw oú $\mu \varphi v \tau o v \pi v \varepsilon \tilde{u} \mu \alpha$ as it appears in the de Generatione Animalium in those passages of the de Anima where Dr Peck inferred its presence, namely in the discussion of how animal locomotion occurs in 3.10, 433b 8-30.41 The word $\sigma u ́ \mu \varphi v \tau o v$ does not appear in Stephanus' discussion (587.21-591.19). And yet 
they would have found it useful to have such a concept ready made in Aristotle. An explanation of its absence could be that they were simply not familiar with either the de Generatione, or the de Motu, where it also appears. It may be significant that both were among that group of biological and zoological works which were left without commentaries until Michael of Ephesus produced them, as part of the twelfth century project organised by Anna Comnena to fill gaps in the corpus of commentaries. ${ }^{42} \mathrm{Be}$ that as it may, de Anima 3.10 contains no reference to pneuma, while Stephanus introduces it at several points in his exposition with, as usual, no indication that it has been imported, either from other Aristotelian works, or

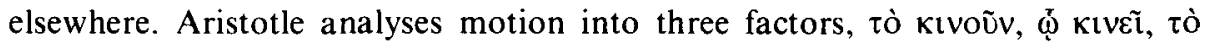

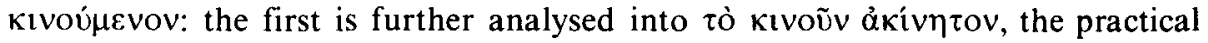

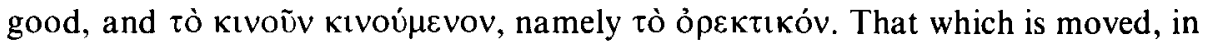
the tripartite analysis, is the $\zeta \tilde{\varphi} o v$, and ö $\rho \varepsilon \xi 1 \zeta$ moves it by means of a bodily

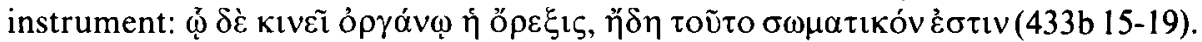

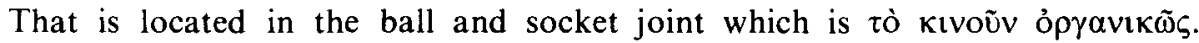
Stephanus tells us that by ópyavikóv Aristotle means the pneuma that runs through the nerves from the heart. 'Opravikóv is not Aristotle's word, and by substituting it for ob $\rho$ qvov Stephanus has facilitated his introduction of pneuma,

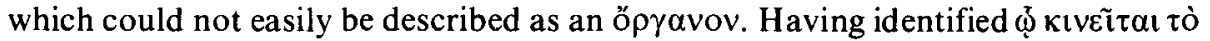
$\sigma \tilde{\omega} \mu \alpha$ with that, he can now go on to say that since body is moved by pneuma,

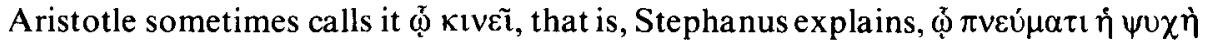

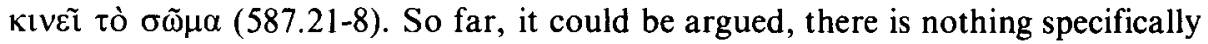
Platonist about his use of pneuma, and though it is not present in the Aristotelian text, we need not go beyond Hellenistic medicine for a possible source. ${ }^{43}$ But when Stephanus continues to explain Aristotle's selection of the ball and socket joint as the place where the beginning and end of motion coincide, we again see him working with Neoplatonic concepts. For he says that Aristotle makes his

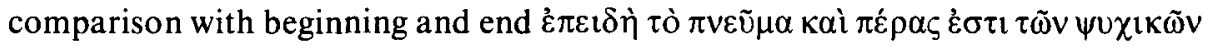

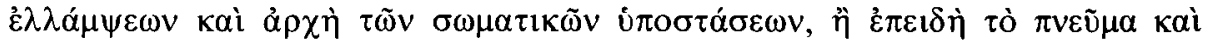

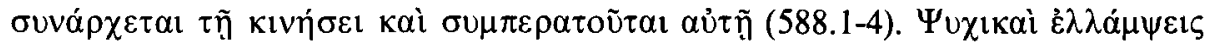
have of course nothing to do with Aristotle. They are the successive radiations of soul, which produces them as its lower levels - here they may be assimilated to Aristotelian faculties - and subsequently as matter. They may also be described as

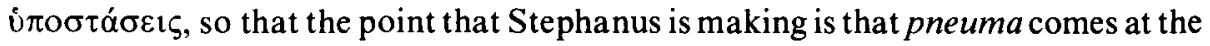
point of transition between purely psychic and corporeal existence. It is because of its intermediate status that it is the material for the not fully corporeal body in which souls are clad before they can function in or through a body. Given this, it is likely that it is the Neoplatonic concept of pneuma that appears a page later, in the commentary on Aristotle's brief comparison of the starting point of motion, with its two components behaving in different ways, to the case of a circle, where something moves while something else stays still. The immediate point of comparison is motion taking place 
comments that Aristotle is also comparing the pneuma to a circle because in a circle

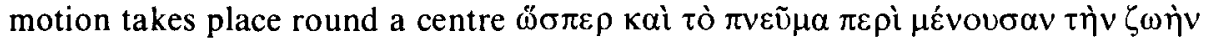

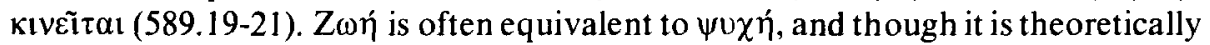
possible that the association of pneuma with circular motion arises from an old confusion of pneuma with Aristotle's $\alpha i 9 \eta \rho^{44}$ it is unlikely that Stephanus is thinking of the natural motion of the fifth element, rather than the Neoplatonic motion of pneuma round soul. 45

Nevertheless there is an Aristotelian text which does connect pneuma with the movement of animals, and more specifically with both ö $\rho \varepsilon \xi_{\mathrm{l}} \varsigma$ as a middle term and

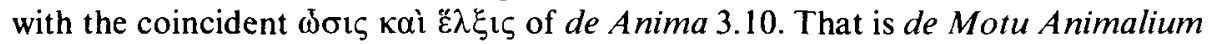
703a 14-28. This could be the text to which Simplicius refers when he cites the de Motu in his commentary on de Anima 3.10 (301.18), and we must allow the possibility that this was in Stephanus' mind too. If that appears to be a grudging admission, thus made to support a poor case for Stephanus' Neoplatonic bias on this point, let it be added, first, that this chapter, 10, of the de Motu is itself problematic, being at least at first sight an excrescence on that work, where movement is otherwise explained without recourse to pneuma, ${ }^{46}$ and, secondly, that Simplicius is known to have read, and recorded details of, works which others did not know or neglected. ${ }^{47}$ But that may be to attribute too much to Simplicius in this instance. Professor Nussbaum, who has examined the ancient allusions to the de Motu, concluded that Philoponus (she does not distinguish the true and false Philoponus) appeared to know nothing of the contents of the work even though he does refer to it. ${ }^{48}$ As for Simplicius, Nussbaum thinks that he is confused about the contents of de Motu. ${ }^{49}$ I should say that two further references two pages below the one we have mentioned would, at least, be compatible with Simplicius not having read the work at all: the second seems to suggest that he had not (303.15-16 and 21$3)$.

To return to his exposition of de Anima 3.10. After reducing the importance of pneuma by saying that one might refer to the boundary between what is moved and what remains at rest as either $\dot{\varepsilon} \pi ı \varphi \alpha ́ v \varepsilon 1 \alpha$ - which it is tempting to translate as 'interface' - or pneuma, but that in any case the things involved are corporeal, he proceeds to resolve the problem into one about levels of soul, and so introduces two Platonist notions. The first is that the soul as $\varepsilon v \tau \varepsilon \lambda \varepsilon \dot{\varepsilon} \chi 1 \alpha$ of the body uses the living

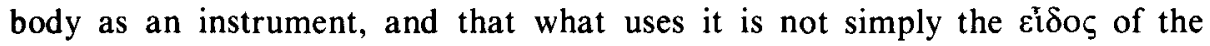
instrument. The second is in the reason he gives here, namely, $\dot{\varepsilon} \xi \underline{n} \rho \eta \tau \alpha$....

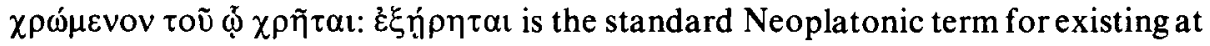
a higher level (301.26-36), ${ }^{50}$ it is the $\zeta \tilde{\omega} 0 v$ not, we may note, the body, which is set below. The soul which imparts movement is not the informing life of the body: ouk

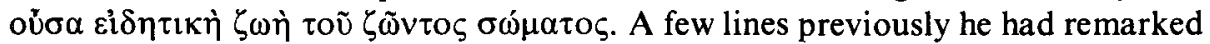
that the vegetative soul $\dot{\alpha} \mu v \delta \rho \tilde{\omega} \zeta \dot{\varepsilon} \mu \varphi \alpha i v \varepsilon$ iò $\chi \rho \omega ́ \mu \varepsilon v o v$, and if, as seems to be the case, the classical connotations of $\varepsilon_{\mu} \varphi a^{\prime} v \omega$, reflections or mirror-images, still hold, ${ }^{51}$ that would be the other side of the Neoplatonic relation we have already 
observed in connection with Stephanus' use of ह̌ $\lambda \lambda \alpha \mu \psi \imath \iota(301.36-302.17)$.

The search for a Platonist reading of Aristotle may be found expressed in

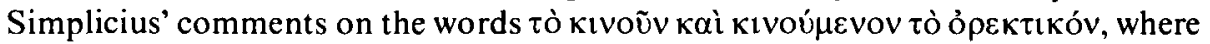
Alexander's explanation is rejected in favour of Plutarch's. Alexander explains, Simplicius reports, that of $\rho \varepsilon \xi \downarrow$ is moved accidentally. While we might think that this is clearly the correct understanding of Aristotle's thought, Simplicius, who takes Kıvoú $\mu \varepsilon v o v$ as referring to the arousal to a state of actually desiring by the object of desire, tells us that Plutarch's interpretation is to be preferred $\kappa \dot{\alpha} \lambda \lambda$ iov

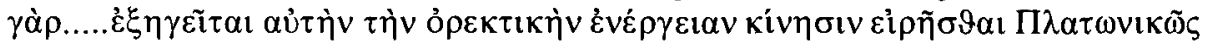

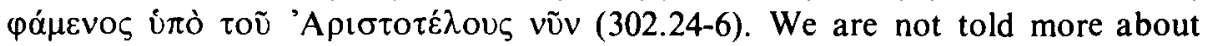
Plutarch's reasoning. Simplicius supplies us with his view of what it might have been. But in any case the background to it is likely to have been the Neoplatonists' view that everything done by the soul is an $\dot{\varepsilon} v \varepsilon \gamma \varepsilon \varepsilon \alpha$ in the sense of an active rather than passive involvement in any function. Part of his suggested explanation of

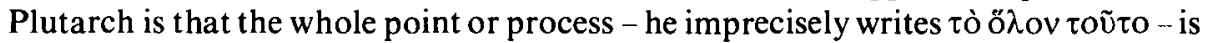

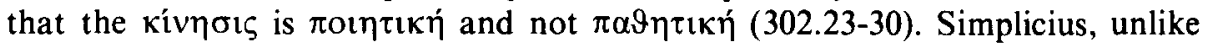
Stephanus, does not take the $\sigma \omega \mu \alpha \tau$ เ $\sigma \omega \mu \alpha \tau \iota \kappa o ́ v \varepsilon \dot{\varepsilon} \sigma \tau \iota$ as a reference to pneuma but, saying that $\sigma \omega \mu \alpha \tau \iota \kappa o ́ v$ is not $\sigma \tilde{\omega} \mu \alpha$,

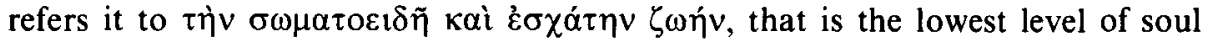
(303.9-10).

Simplicius' treatment of the discussion about how to divide the soul, which in the de Anima (3.9) leads up to the section on movement, offers an interesting example of the methods used to show Aristotle and Plato in agreement with each other. Aristotle objected to Plato's tripartition on the grounds that certain powers of soul, as he analysed it, cut across Plato's divisions. Appetition in particular appears at all levels of soul and Aristotle stresses that it should not be split: kai ä

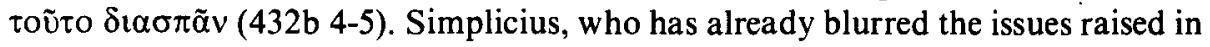
de Anima 3.9 by saying that the soul can be divided up in any number of ways (288.37-289.5), tells us that Plato in the Republic did not intend a division of the whole soul, but only of what was needed for practical life. He compares Plato's procedure with Aristotle's in the Nicomachean Ethics, where he reads into the

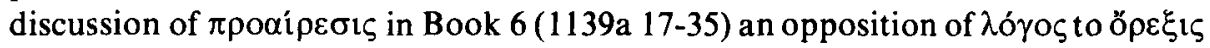
(289.14). In making these points Simplicius not only jettisons the results of the de Anima analysis, but distorts that of the Ethics too. He then concludes that Plato

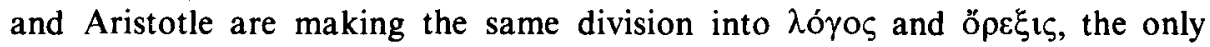
difference being that Plato has further divided irrational ö $\rho \varepsilon \xi ı \varsigma$ into $\vartheta u \mu o$ ó and $\dot{\varepsilon} \pi ı \vartheta \mu i \alpha$, which, Simplicius tells us, was necessary for educational purposes: $\tau \alpha \tilde{\tau} \tau \alpha$ $\mu \dot{\varepsilon} v$ í $\pi$ ò $\Pi \lambda \alpha \dot{\alpha} \omega v o \varsigma \alpha \dot{\alpha} \pi \circ \lambda \varepsilon \lambda \sigma \gamma \eta \dot{\sigma} \vartheta \omega$ he concludes (289.7-19). We may take leave to doubt whether Aristotle would have accepted the apology. What we have is another demonstration of how to find $\sigma \nu \mu \varphi \omega v i ́ a$ between Plato and Aristotle by reading them 'not in a superficial manner'.

Stephanus' treatment of de Anima 3.9 is more complicated, but it does show that 
not all the commentators always went to the same lengths in explaining away differences between Plato and Aristotle. Stephanus complained that Plutarch as well as Alexander said that Aristotle criticised Plato for dividing the soul into parts,

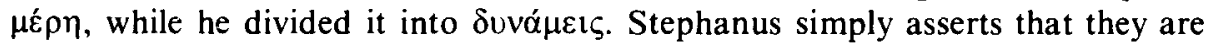

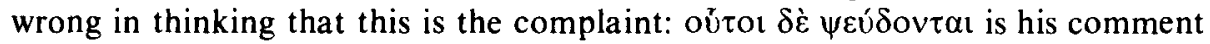
(571.34-572.1). Nevertheless after setting out, overschematically, Aristotle's objections to Plato's division, and mentioning the defences that were made (571.27-

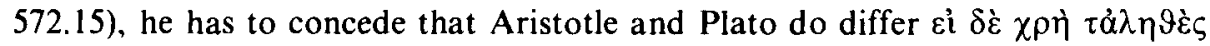

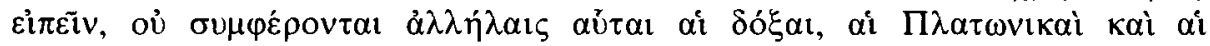

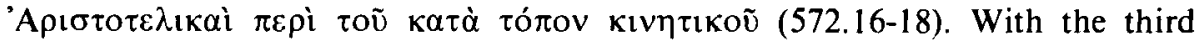
objection in his list he adduces the point that Simplicius had evaded: $\delta 1 \alpha \sigma \pi \tilde{\alpha}$ oṽ tò

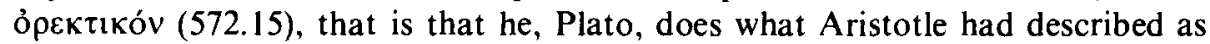
absurd. All of this does not prevent Stephanus from translating Aristotle's supposed objection into Neoplatonic terms en route, for one of three points that he

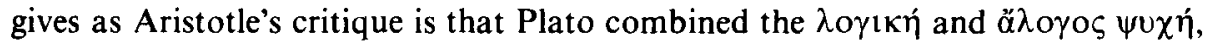
two more or less distinct entities for Stephanus, and then split the resultant unit into three.

This is not the only occasion on which the commentators who remained in the direct Ammonius tradition - Philoponus and Stephanus - are readier to admit differences between Plato and Aristotle than was Simplicius. Philoponus' treatment of Aristotle's definition of the soul, and of the $\pi \lambda \omega \tau \eta$ p problem, which I have discussed elsewhere, ${ }^{52}$ show similar tendencies. But that does not alter the fact that they did, in general, feel an obligation to harmonize the texts wherever they could, and that they tended to do this by seeing Aristotle and Plato as Neoplatonists like themselves.

The few passages we have looked at may serve to exemplify both this overall approach, and its detailed application. It is a curious irony that the charges so often made against Aristotle himself, that he traduced the thought of the pre-Socratics, and even Plato himself, by translating it into his own terms and then assessing what he saw as their answers to his questions, might with more justice be made against those who expounded Aristotle himself at the end of Classical Antiquity. And they went one step further. They caused Aristotle to give their own Platonist answers on almost every occasion when they saw him solving their particular set of problems. Once his work had been processed in this way they no longer had grounds for treating Aristotle as he had treated his predecessors, saying of the Platonists

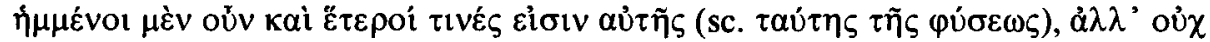
ikavãs (Physics 1.191b 35-6). All that was likely to be missing was a clear expression of the truth to which he could not fail to have assented. As Aristotle had

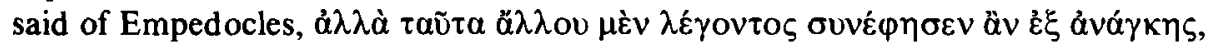

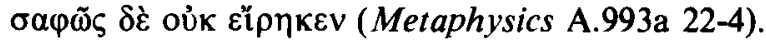




\section{NOTES}

1. Unless otherwise specified all references to Aristotle are to the de Anima, and all unspecified references to the Aristotelian commentators to their de Anima commentaries. The commentators are cited by page and line of the Berlin Academy edition.

2. Themistius is to be excluded from this group, notwithstanding certain Platonist sympathies, cf. my 'Themistius, the last Peripatetic commentat or on Aristotle?', in Arktouros: Hellenic Studies presented to Bernard M. W. Knox (1979) 391-400.

3. Cf. Asclepius, in Metaph. 166.35-6; Simplic., in Phys. 1249.12-13; I. Düring, Aristotle in the ancient biographical tradition, Stud. Gr. et Lat. Gothoburgensia 5 (1957) 332-6.

4. Cf. Cic. Acad. 1.4.17.

5. Cf. e.g. Simplic., in de Caelo 454.23-9.

6. Cf. 'Neoplatonic elements in the de Anima commentaries', Phronesis 21 (1976) 64-87, hereafter 'Neoplatonic elements'.

7. See n. 2.

8. Cf. K. Praechter's classic study, 'Richtungen und Schulen im Neuplatonismus', in Genethliakon C. Robert (1910) esp. 144-55, reprinted in Kleine Schriften. ed. H. Dörrie (1973), and his RE articles on Hierocles and Simplicius; see further the references in I. Hadot, Le problème du Néoplatonisme alexandrin: Hiéroclès et Simplicius (1978) 12-13.

9. Cf. H.-D. Saffrey, 'Le Chrétien Jean Philopon et la survivance de l'école d'Alexandrie au VI' siècle', REG 67 (1954) 396-8, and the list of Proclus' disciples in Proclus, Théologie Platonicienne, ed. H.-D. Saffrey and L. G. Westerink, I (1968) xlix-liv.

10. See n. 8; cf. also the reservations already expressed by A. C. Lloyd in The Cambridge History of later Greek and early medieval philosophy, ed. A. H. Armstrong (1967) 314-16.

11. 'The last days of the Academy at Athens', PCPS n.s. 15 (1969) 9. See too Saffrey (n. 9) 399-401, and the qualifications made by Westerink, Anonymous Prolegomena to Platonic philosophy (1962) xi-xiii.

12. Cf. Plotinus 5.1.8.10-14; Proclus, in Alc. 227.21-2.

13. 'Neoplatonic elements' $72-9$.

14. [Philop.] 535.2-19.

15. These problems were the most frequently treated, cf. P. Moraux, 'Le de Anima dans la tradition grecque. Quelques aspects de l'interprétation du traité, de Théophraste à Thémistius', in Aristotle on mind and the senses, Proc. of the seventh Symposium Aristotelicum, ed. G. E. R. Lloyd and G. E. L. Owen (1978) 283; on the controversy about voũ cf. 'Neoplatonic elements' 73-7.

16. Cf. e.g. Plot. 4.7.85. 2-3 and my Plotinus' psychology (1971) 12-13; G. Verbeke, 'Les critiques de Plotin contre l'entéléchisme d'Aristote: essai d'interprétation de l'Enn.4.7.8', in Philomathes. Studies and essays in the humanities in memory of P. Merlan, ed. R. B. Palmer and R. Hammerton-Kelly (1971) 199 and n. 15.

17. Cf. Plotinus' psychology 112-33 and my 'Nous and Soul in Plotinus: some problems of demarcation', in Atti del convegno internazionale sul tema: Plotino e il Neoplatonismo in oriente e in occidente, Rome, 5-9.10.1970, Accademia nazionale dei lincei: Problemi attuali di scienza e di cultura 198 (1974) 217-19; for another view see T. A. Szlezák, Platon und Aristoteles in der Nuslehre Plotins (1979) 170-98. 
18. Cf. e.g. R. T. Wallis, Neoplatonism (1972) 130-2.

19. For the earlier Neoplatonists cf. esp. P. Hadot, Porphire et Victorinus (1968) I, ch. 5.

20. De Mem. 450a 9-14; de Somn. 455a 12-26; for a recent summary of views see R. R. K. Sorabji, Aristotle on memor!' (1972) 74-6.

21. By F. Bossier and C. Steel, 'Priscianus Lydus en de "in de Anima" van pseudo(?)-Simplicius', TPh 34 (1972) 761-822, who find both stylistic and doctrinal differences from the other works of Simplicius; the presence of the latter is denied by I. Hadot (n. 8) 193-202.

22. Cf. further Plotinus' psycholog. (n. 16) 70-2.

23. Cf. H.-R. Schwyzer, 'Zu Plotins Interpretation von Platons Timaeus 35A', RhM 84 (1935) 363-8.

24. Cf. e.g. Plot. 4.1; Proclus, El.Th. 195.

25. For a fuller discussion see 'Neoplatonic elements' 83-4.

26. See n. 16.

27. Thus, e.g. Simplic. 1.14-20.

28. Cf. my 'Soul, world-soul and individual soul in Plotinus', in Le Néoplatonisme. Colloques internationaux du C.N.R.S. Royaumont 9-13.6.1969 (1971) 60.

29. Cf. e.g. Proclus, in A/c. 122-3; see also R. B. Todd, 'Epitedeiotes in philosophical literature: towards an analysis', AClass 15 (1972) 31 and n. 27.

30. See e.g. Proclus, El. Th. 166, 182-4.

31. The reference is probably to his lost commentary on the de Anima, but the point may be found in his independent treatise on the soul, de An. 23.24-24.9.

32. See nn. 8 and 10 .

33. Fr. 7 Ross.

34. Cf. 'Neoplatonic elements' 73-7.

35. Ibid. 76-7, 79-81.

36. Cf. Alex., de An. 20.26-21.11.

37. Cf. Proclus, El. Th. 64, with Dodds' note ad loc.; A. Smith, Porphyry's place in the Neoplatonic tradition (1974) 7-19.

38. 18.22-33.

39. Cf. also Tim. 69C.

40. This paper was given at Christ's College.

41. Cf. de Generatione Animalium ed. A. L. Peck (1942) App. B, 576-8.

42. Cf. Praechter, reviewing CAG 22.2, GGA (1906) 862-4 (reprinted in Kleine Schriften, see n. 8); R. Browning, "An unpublished funeral oration on Anna Comnena', PCPS n.s. 8 (1962) 7-8. 
43. Cf. F. Solmsen, 'Greek philosophy and the discovery of the nerves', $M H 18$ (1961) 178-90.

44. On this see S. Sambursky, Stoic physics (1959) 34; H. J. Easterling, 'Quinta natura', MH 21 (1964) esp. $81-3$.

45. Cf. Plot. 2.2.2.19-26.

46. Cf. M. C. Nussbaum, Aristotle's de Motu Animalium (1978) 143-64.

47. Cf. G. S. Kirk and J. E. Raven, The Presocratic philosophers (1957) 1.

48. Nussbaum (n. 46) 6 and n. 15, referring to a fuller discussion in her Harvard doctoral dissertation.

49. Ibid.

50. Cf. Simplic. 195.30-1; Proclus, El. Th.5I and 75.

51. Cf. the somewhat earlier uses in Proclus, in Alc. 320.10-11, in Eucl. 94.21-5.

52. 'Neoplatonic elements' $85-6$. 